\title{
COMPUTERIZATION OF EDUCATION. ETHICS IN INTERNATIONAL DISTANCE EDUCATION AT MEDICAL UNIVERSITIES
}

Podurueva-Miloevich VYu ${ }^{1}$, Krivosheeva $\mathrm{NI}^{2}$, Martinson ZhS ${ }^{1}$

${ }^{1}$ Volgograd State Medical University, Volgograd, Russia

${ }^{2}$ Volgograd Institute of Management, The Russian Presidential Academy of National Economy and Public Administration, Volgograd, Russia

The article deals with ethical aspects of psychological and pedagogical approach of teaching international medical students in the process of educational computerization at modern universities. Particular attention is paid to studying the basics of psychology and pedagogy and mechanisms of distance learning, taking into account cognitive and personal traits of students to develop their professional knowledge, skills and competencies.

Key words: distance learning, international students, computerization of education, ethical aspect, intercultural competency

Author contribution: Martinson ZhS has collected actual data. Krivosheeva NI has performed primary analysis of actual data. Podurueva-Miloevich VYu has detected characteristics of the basics of psychology and pedagogy and mechanisms of distance learning, conducted an empirical study (survey), and analyzed an ethical aspect, considering cognitive and personal traits of students.

Correspondence should be addressed: Victoria Yu. Podurueva-Miloevich

pl. Pavshikh bortsov, 1, Volgograd, 400131, Russia; viktorija-milojevic@yandex.ru

Received: 07.08.2021 Accepted: 23.08.2021 Published online: 30.09.2021

DOI: $10.24075 /$ medet.2021.0220

\section{ИНФОРМАТИЗАЦИЯ ОБРАЗОВАНИЯ. ЭТИЧЕСКИЙ АСПЕКТ ДИСТАНЦИОННОГО ОБРАЗОВАНИЯ ИНОСТРАННЫХ УЧАЩИХСЯ В МЕДИЦИНСКОМ ВУЗЕ}

В. Ю. Подуруева-Милоевич ${ }^{1}$, Н. И. Кривошеева ${ }^{2}$, Ж. С. Мартинсон ${ }^{1}$

${ }^{1}$ Волгоградский государственный медицинский университет, Волгоград, Россия

${ }^{2}$ Волгоградский институт управления, Российская академия народного хозяйства и государственной службы при Президенте РФ, Волгоград, Россия

\begin{abstract}
В статье рассмотрен этический аспект психолого-педагогического подхода в обучении иностранных студентов-медиков в процессе инсорматизации образования в современном вузе. Большое внимание уделяется изучению психолого-педагогических основ и механизмов дистанционного обучения, учитывающих когнитивные и личностные особенности обучающихся в целях формирования у студентов профессиональных знаний, навыков и компетенций.
\end{abstract}

Ключевые слова: дистанционное обучение, иностранные студенты, информатизация образования, этический аспект, межкультурная компетенция

Вклад авторов: Мартинсон Ж. С. - сбор фактического материала; Кривошеева Н. И. - первичный анализ фактического материала; ПодуруеваМилоевич В. Ю. - выявление характеристик психолого-педагогических основ и механизмов дистанционного обучения, эмпирическое исследование (анкетирование), а также рассмотрение этического аспекта, учитывающего когнитивные и личностные особенности обучающихся.

$\triangle$ Для корреспонденции: Виктория Юрьевна Подуруева-Милоевич пл. Павших борцов, 1, г. Волгоград, 400131, Россия; viktorija-milojevic@yandex.ru

Поступила: 07.08.2021 Статья принята к печати: 23.08.2021 Опубликована онлайн: 30.09.2021

DOI: $10.24075 /$ medet.2021.022

The path of development of domestic systems of higher education, as well as of entire pedagogy, is rather complicated and has its ups and downs. Its fundamentals were obviously deformed in the stages of the cult of personality and stagnation. The majority of pedagogical problems, which objectively occurred at the time of restructuring of all areas of public life and activity, couldn't be solved successfully. The task of the modern educational system is to raise a highly-educated, intelligent person with a holistic worldview who understands and comprehends the depth of the link between phenomena and processes forming the worldview.

In modern society, a computer is used almost in every sphere of a human life. Education is computerized to the largest extent. Computerization of education is treated as 'an objective and consistent process providing the educational sector with methodology and practice of development and optimal usage of information and communication technology (ICT) tools' [1].

It is of note that the principle of priority of a pedagogical approach during computerization is a feature of the modern
Russian higher education system. Any implementation and use of ICT in education starts with pedagogical planning. The latter inevitably requires asking questions about who educates, who is educated, what and how is taught, etc. The pedagogical system embraces a purpose, contents, tools, methods, forms, the one who educates and the one who is educated. This is the reason why computerization and intensification of ICT implementation into the educational sphere don't modify a set of component data. 'It is obvious that educational tools are just transportation means used to deliver knowledge to students. However, the means do not influence acquisition of knowledge, just like a lorry, delivering products, produces no effect on the product nutritional value' [2].

Thus, ICT development gave rise to new conditions of learning and dealing with data in the educational system. Distance learning and ICT-rich educational environment are fundamentals of modern education. If, before the pandemic of 2020, distance education was widely used in the system of higher education as an additional offer as compared to traditional forms of teaching and learning, it, for now, becomes 
almost the principal way of getting education. It can be asserted that being an educational core, learning undergoes certain modification, namely, its procedural component (the process of direct transfer of and gaining experience in the course of teacher-student interaction) is modified [3]. In other words, learning forms are changed, whereas its essential aspects stay unchanged. For example, transition of learning into electronic educational environment still requires targeted management aimed at the formation of professional knowledge, skills, competencies, and creative capacities in students.

Distance learning is 'a targeted process of interactive communication between those who educate, those who are educated and educational tools, which is indifferent to how all the participants are located in space and time, and which is implemented in the specific didactic system' [4].

Distance learning features are as follows:

- physical separation of teachers and students;

- physical separation of students and schools;

- asynchronous learning (diversity in time);

- interactive communication between teachers and students;

- interactive communication between students, and students and tools. In distance education, we always learn using tools;

- continuous academic activity of students:

- distance training course, selected educational materials;

- possible in-person learning.

A distance learner is usually isolated. Distance learning doesn't only lack motivating factors resulting from interaction or competition with other students during in-person lessons. It also lacks the necessary direct support from a teacher, who can motivate and pay attention to those needs and difficulties that arise in the course of the educational process. This means that students need to take personal responsibility for their learning process.

In distance learning, being independent (self-determined learning) is a high priority. As students are autonomous, independent learning has two meanings:

1) autonomy is a prerequisite for successful distance learning;

2) autonomy is an ultimate goal for distance learning.

Successful distance learning requires a high level of selfdiscipline and independence, as students have to rely on themselves and their motivation resources only, even more so than in in-person learning. This happens because many factors responsible for extrinsic motivation are available indirectly or lacking at all [5]. In in-person learning, intrinsic motivation is highly desirable. In distance learning, it is a necessary prerequisite.

\section{References}

1. Andreev AA. Handbook po discipline "Pedagogika vysshej shkoly". M., 2012; 47 p. Russian.

2. Nazarenko AL, Rawson-Jones C, Anoshkina Zh G. Distancionnoe obrazovanie i prepodavanie inostrannyh jazykov (opyt fakul'teta inostrannyh jazykov MGU). Moscow University Linguistics Bulletin. 2004; 1: 10. Russian.

3. Uddin MA. Psihologo-pedagogicheskie osobennosti distancionnogo obuchenija i lichnostnye osobennosti studentov, obuchajushhihsja na osnove distancionnyh tehnologij. Psihologicheskaja nauka i obrazovanie. 2012; 5: 38-49. Russian.
Autonomous learning means that students need to cope with tasks that lack previously prepared answers. They are trying to solve the problems that seem relevant to them. Students' degree of self-sufficiency depends on the extent of their participation in research planning and conduction, and assessment of research outcomes. But as practice shows, not every student is ready for distance learning.

Direct or indirect influence on intercultural communication is commonly a decisive factor for previous motivation of international students. The importance of examining their emotions must be stressed as well. The emotional variable is a motivation language learning, whereas emotions are essential motivators. A. Maclntyre believes that relations by themselves are not enough to support motivation in learning, and that we need to take into account students' emotions during the process of learning to find the difference between the students who are interested in learning and those who are not [6].

We can conclude that emotional behavior of international medical students during the learning process can be comprehended the best, when they accept orientations of the studied discipline offered by their teacher, and when they are not stressed trying to accept them.

In this article, we report online survey results for medical international $1^{\text {st }}$ year students. The survey shows that out of 100 students participating in the survey, the majority of those requested mentions a complex interaction of social and biographical variables in their perception of the Russian language and its use to express their emotions, and a mental effect obtained when one studies in an international language. Good emotional atmosphere can't be created by students only. $84 \%$ of those requested note that teachers are ultimately responsible for a positive learning environment; the students are concerned about emotions in class.

On the one hand, teachers need to structure their discourse so that it could be easily comprehended by international students. On the other hand, teachers have to create a true teaching environment using verbal and nonverbal tools, when international students believe in the value of education in Russian and understand that higher education is important.

Thus, distance learning requires high independence, self-discipline, good organization and time management. Consequently, based on modern realities, pedagogical activity must be aimed at development of these personal qualities in students. We need to concentrate on complex development of a model researching the basics of psychology and pedagogy and mechanisms of distance learning that could take into account both cognitive and personal traits necessary for distance learning, and effect of ICT on development of these traits in students. 


\section{OPINION}

\section{Литература}

1. Андреев А. А. Handbook по дисциплине «Педагогика высшей школы». М., 2012; 47 с.

2. Назаренко А. Л., Роусон-Джонс К., Аношкина Ж. Г. Дистанционное образование и преподавание иностранных языков (опыт факультета иностранных языков МГУ). Вестник Московского университета. Изд-во Московского университета. Серия 19 лингвистика и межкультурная коммуникация. 2004; 1: 10.

3. Уддин М. А. Психолого-педагогические особенности дистанционного обучения и личностные особенности студентов, обучающихся на основе дистанционных технологий. Психологическая наука и образование. 2012; 5: 38-49.

4. Андреев А. А., Солдаткин В. И. Дистанционное обучение: сущность, технология, организация. М.: Изд-во МЭСИ, 1999; 196 C.

5. Schuemer R. Some Psychological Aspects of Distance Education. Fern Univ., Hagen (Germany). Inst. for Research into Distance Education. FernUniversitat - Gesamthochschule - in Hagen. 1993; $40 \mathrm{p}$

6. Maclntyre A. Ethics and Politics: Selected Essays. Cambridge University Press, 2006; 2: 147. 